\title{
Solubility of $\beta$-cyclodextrin in different mixed solvents
}

\author{
Yu Yong, Li Jiguang, Sun Yan, Liang Qianqing, Peng Xiaoming, Liu \\ Yansheng and Hu Yufeng*
}

Laboratory of Green Chemistry and Chemical Engineering, China University of Petroleum, Beijing 102249, China

\begin{abstract}
The solubility of $\beta$-cyclodextrin ( $\beta$-CD) in ionic liquid/N, N-dimethyl-acetamide (IL/DMAC) mixed solvent and in $\mathrm{LiCl} / \mathrm{DMAC}$ mixed solvent was investigated at $323.15 \mathrm{~K}$ and $353.15 \mathrm{~K}$. The results showed that the solubility of $\beta-\mathrm{CD}$ in IL/DMAC system increased with increasing temperature, but decreased in $\mathrm{LiCl} / \mathrm{DMAC}$ system. $\beta$-CD had the highest solubility in IL/DMAC system with $[\mathrm{Cl}]^{-}$or $[\mathrm{Br}]^{-}$ anions. The solubility of $\beta$-CD in $\mathrm{LiCl} / \mathrm{DMAC}$ system was lower than that in IL/DMAC system with $[\mathrm{Cl}]^{-}$or $[\mathrm{Br}]^{-}$anions but higher than that in IL/DMAC system with weak-coordinated anions (e.g $\left[\mathrm{BF}_{4}\right]^{-}$ or $\left[\mathrm{PF}_{6}\right]^{-}$). The effects of substituent groups (benzyl and butyl) of cation and the structure of cations on $\beta$-cyclodextrin solubility were also investigated.
\end{abstract}

Key words: $\beta$-cyclodextrin, ionic liquid, solubility, mixed solvent

\section{Introduction}

Cyclodextrins (CDs) have attracted researchers' attention because they can include inorganic-, organic- and chiralmolecules to form guest-host structures and super-molecules (Kawaguchi et al, 2000). CDs could be described as shallow, truncated cones with a hydrophobic interior. The cavity of CDs can selectively include guest molecules in aqueous solutions (Naidoo et al, 2004). The most important three CDs are $\alpha-\mathrm{CD}, \beta-\mathrm{CD}$, and $\gamma-\mathrm{CD}$ in the order of increasing size (Engeldinger et al, 2003). $\quad \beta$-CD (Figs. 1 and 2), the most readily available one, shows an anomalously low aqueous solubility (1.85 g.100 $\left.\mathrm{mL}^{-1}\right)$ (Chatjigakis et al, 1992), which is a limiting factor for investigation of properties of inclusion compounds formed by this cyclic oligosaccharide. Therefore, understanding molecular mechanisms involving $\beta-\mathrm{CD}$ inclusion compounds is important for applications of CDs in catalytic (Tang et al, 2002), industrial (Mohammad and Razieh, 2007) and pharmaceutical (Denadai et al, 2007) fields. Ionic liquids (ILs) are a group of organic salts that are liquid at room temperature (Welton, 1999; Earle et al, 2000). They have unique physico-chemical properties including: 1) Non-volatility and non-flammability; 2) High thermal stability; 3) Their properties can be fine-tuned, allowing selection of the ILs to replace specific solvents in different processes; 4) The ILs with appropriate structures may have a remarkable selectivity toward aromatic hydrocarbons, thus they can serve as a "green" recyclable alternative to volatile organic compounds that are traditionally used as industrial

*Corresponding author. E-mail: huyf3581@sina.com

Received December 4, 2007 solvents (Huddleston et al, 1998; Hu and Guo, 2005; Liu et al, 2006). In fact, ILs have been successfully applied in many fields to replace traditional organic solvents (Wilkes and Zaworotko, 1992; Wasserscheid and Keim, 2000). In this paper, the solubility of $\beta-\mathrm{CD}$ in a series of mixed solvents of IL/DMAC and $\mathrm{LiCl} / \mathrm{DMAC}$ mixtures was investigated.

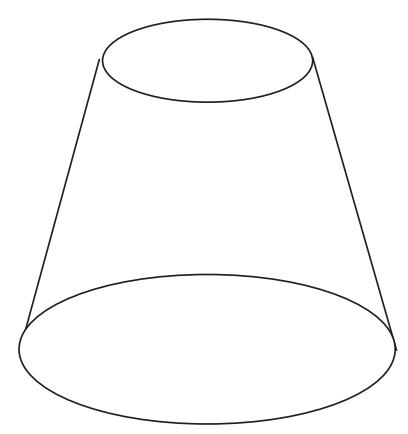

Fig. 1 Side elevation of $\beta-C D$

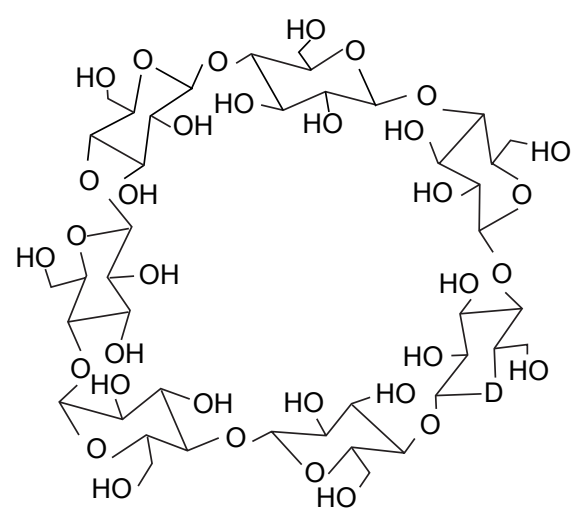

Fig. 2 Planar form of $\beta$-CD 


\section{Experimental}

\subsection{Chemicals}

$\beta-C D$ was obtained from Shanghai Chemical Reagents Company. The sample $\beta$-CD was crystallized twice and dried at $353.15 \mathrm{~K}$ under vacuum for at least $24 \mathrm{~h}$ before use. $\mathrm{N}$, $\mathrm{N}$-dimethyl-acetamide (DMAC) and lithium chloride ( $\mathrm{LiCl})$ were purchased from Beijing Xingjin Chemical Plant and Beijing Yili Chemicals Ltd, respectively. The ionic liquids ([Bemim] [Cl], [ $\left.\mathrm{C}_{4} \mathrm{mim}\right][\mathrm{Cl}],\left[\mathrm{C}_{4} \mathrm{mim}\right][\mathrm{Br}],[\mathrm{BeiQu}][\mathrm{Cl}]$, $\left[\mathrm{C}_{4} \mathrm{iQu}\right][\mathrm{Cl}],\left[\mathrm{C}_{4} \mathrm{iQu}\right][\mathrm{Br}],[\mathrm{BePy}][\mathrm{Cl}],\left[\mathrm{C}_{4} \mathrm{Py}\right][\mathrm{Cl}],\left[\mathrm{C}_{4} \mathrm{Py}\right][\mathrm{Br}]$, $\left[\mathrm{C}_{4} \mathrm{Py}\right]\left[\mathrm{BF}_{4}\right],[\mathrm{BePy}]\left[\mathrm{BF}_{4}\right],\left[\mathrm{C}_{4} \mathrm{mim}\right]\left[\mathrm{BF}_{4}\right]$ and $\left.\left[\mathrm{C}_{4} \mathrm{mim}\right]\left[\mathrm{PF}_{6}\right]\right)$ were all provided by Sigma-Aldrich Company, with purity more than $99.9 \%$. All the chemicals used to prepare ILs were A.R. grade. Deionized water was distilled in a quartz still to a conductivity of $0.8 \times 10^{-4}-1.2 \times 10^{-4} \mathrm{~S} \cdot \mathrm{m}^{-1}$.

\subsection{Experimental method and procedures}

The LiCl/DMAC and IL/DMAC mixtures were prepared by weight fraction, and the mixtures were placed in stoppered conical flasks. Experiments were performed in a thermostat water bath at $323.15 \mathrm{~K}$ or $353.15 \mathrm{~K}$. $\beta$-CD $(0.05 \mathrm{~g}$ each time $)$ was added to $50 \mathrm{~mL}$ solvent mixture at $323.15 \mathrm{~K}$ or 353.15 $\mathrm{K}$ and the solution was stirred by a magnetic stirrer for $24 \mathrm{~h}$, repeating the operation this way until it reached saturation, then the solubility of $\beta$-CD was determined as follows: First, optical rotation was measured with known concentrations of $\beta-C D$ in the solvent mixtures, and a linear relationship was obtained between concentration of $\beta-\mathrm{CD}$ and optical rotation, then the solubility of $\beta$-CD in the mixed solvent could be determined easily by measuring the optical rotation of the solution.

\section{Results and discussion}

\subsection{Effect of temperature and concentration on solubility of $\beta-C D$}

The solubility of $\beta$-CD in $\mathrm{LiCl} / \mathrm{DMAC}$ and in IL/DMAC was determined at $323.15 \mathrm{~K}$ and $353.15 \mathrm{~K}$. The results showed that the solubility of $\beta$-CD increased with increasing temperature in IL/DMAC system, but decreased with increasing temperature in $\mathrm{LiCl} / \mathrm{DMAC}$ system (Figs. 3-10). At the same temperature, the solubility of $\beta$-CD increased with increasing concentration of $\mathrm{IL}$ and $\mathrm{LiCl}$ in mixed solvents.

\subsection{Effect of cation structure on solubility of $\beta-C D$}

Figs. 11-13 show that the solubility of $\beta$-CD in ILs with $[\mathrm{Cl}]^{-}$or $[\mathrm{Br}]^{-}$anions and the common alkyl tail group of cation decreases in the order of imidazolium $>$ isoquinolinium $>$ pyridinium. Fig. 14 shows that the solubility of $\beta-\mathrm{CD}$ in ILs with weakly-paired anions $\left(\left[\mathrm{BF}_{4}\right]^{-}\right.$or $\left.\left[\mathrm{PF}_{6}\right]^{-}\right)$and the same alkyl tail group of cation decreases in the order of pyridinium $>$ imidazolium.

For ILs with halogen anion $\left([\mathrm{Cl}]^{-}\right.$or $\left.[\mathrm{Br}]^{-}\right)$, Figs. 11 and 12 indicate that the ability of forming $\mathrm{H}$-bond between isoquinolinium ILs and $\beta$-CD is weaker than that between

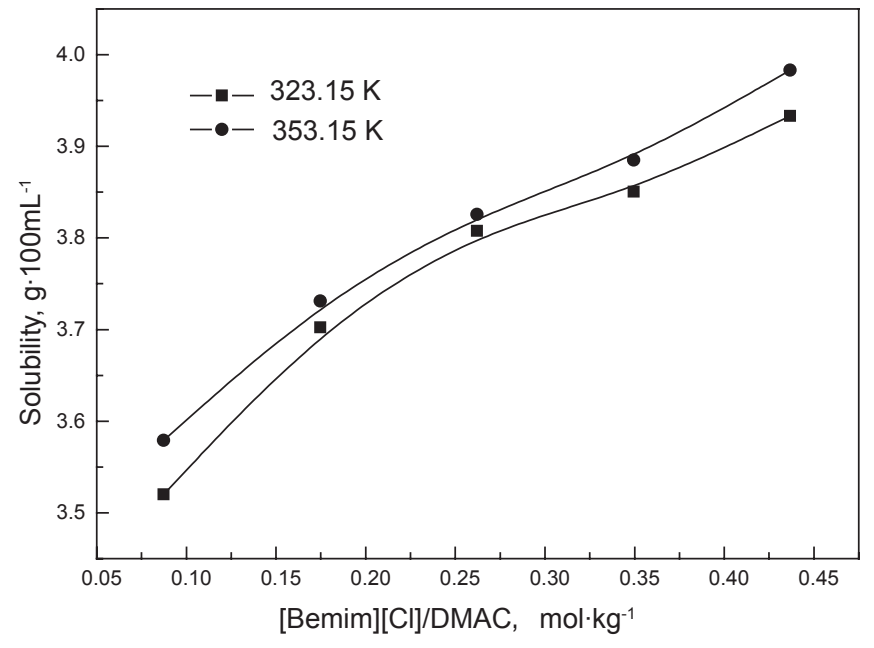

Fig. 3 Effect of temperature and concentration on solubility of $\beta$-CD in $[$ Bemim $][\mathrm{Cl}] / \mathrm{DMAC}$ mixture

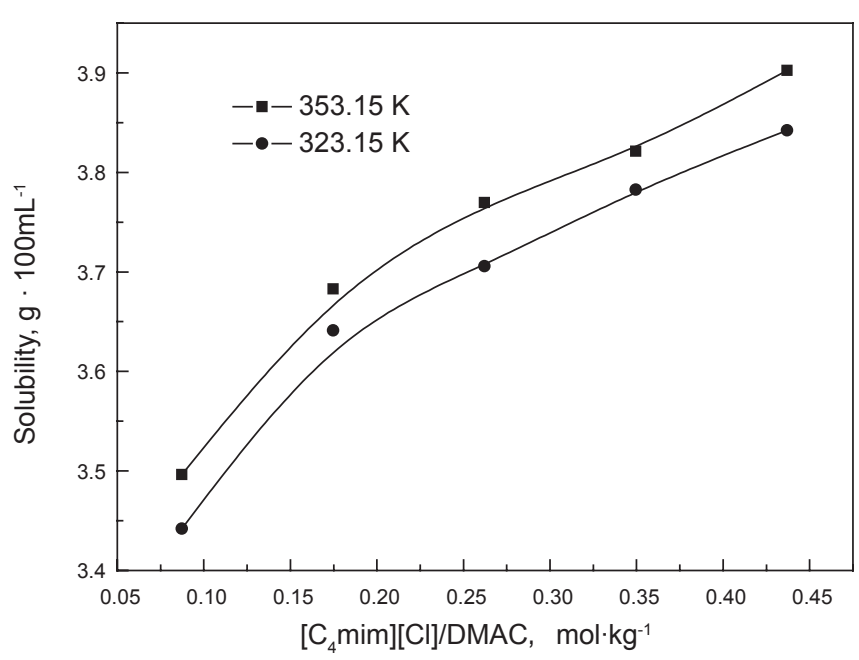

Fig. 4 Effect of temperature and concentration on solubility of $\beta-\mathrm{CD}$ in $\left[\mathrm{C}_{4} \mathrm{mim}\right][\mathrm{Cl}] / \mathrm{DMAC}$ mixture

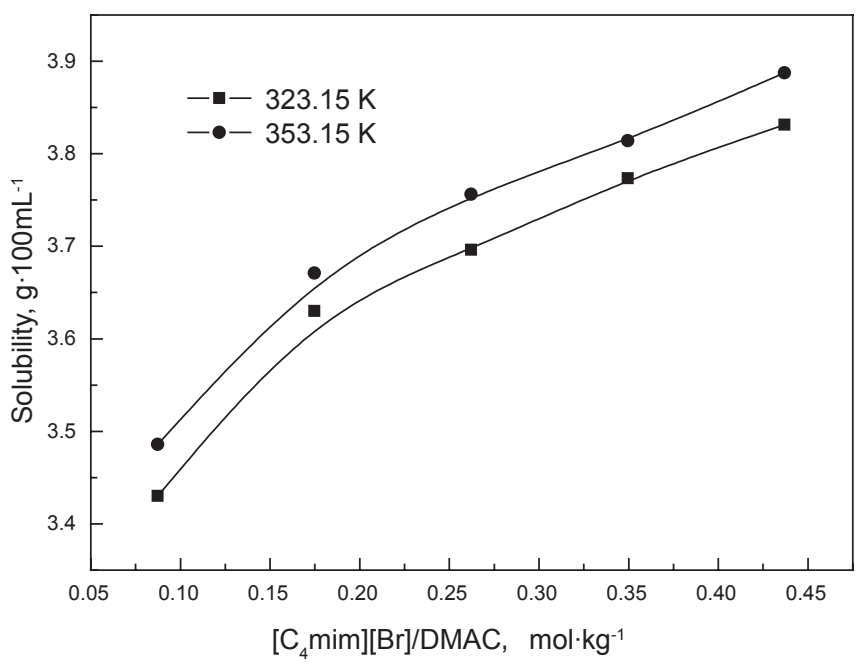

Fig. 5 Effect of temperature and concentration on solubility of $\beta$-CD in $\left[\mathrm{C}_{4} \mathrm{mim}\right][\mathrm{Br}] / \mathrm{DMAC}$ mixture 


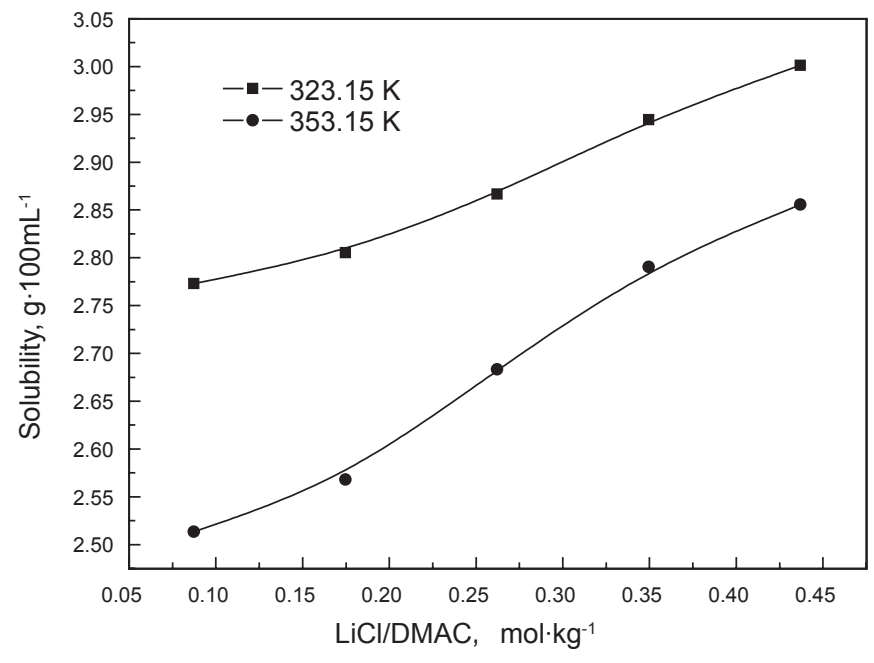

Fig. 6 Effect of temperature and concentration on solubility of $\beta-\mathrm{CD}$ in $\mathrm{LiCl} / \mathrm{DMAC}$ mixture

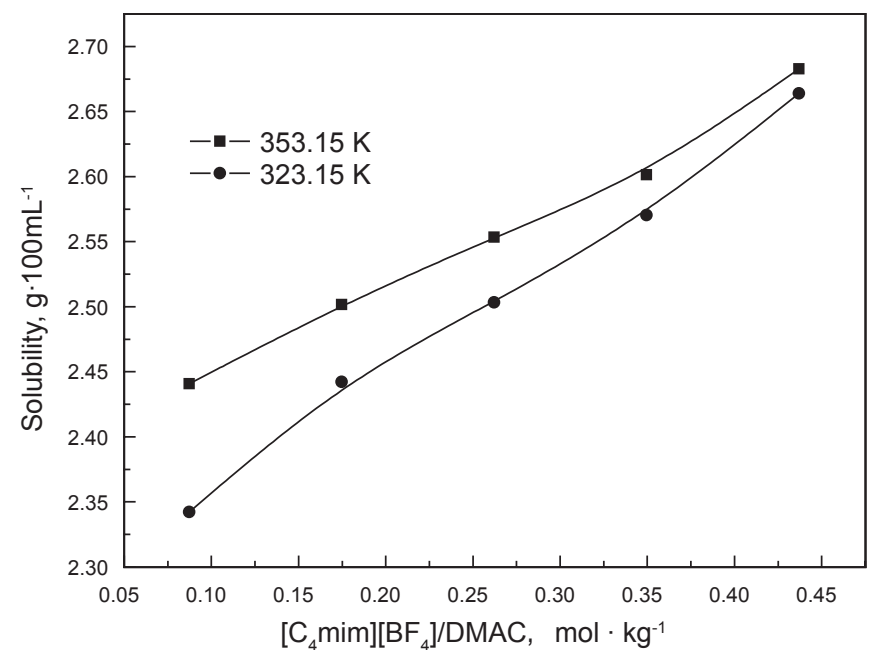

Fig. 7 Effect of temperature and concentration on solubility of $\beta$-CD in $\left[\mathrm{C}_{4} \mathrm{mim}\right]\left[\mathrm{PF}_{6}\right] / \mathrm{DMAC}$ mixture

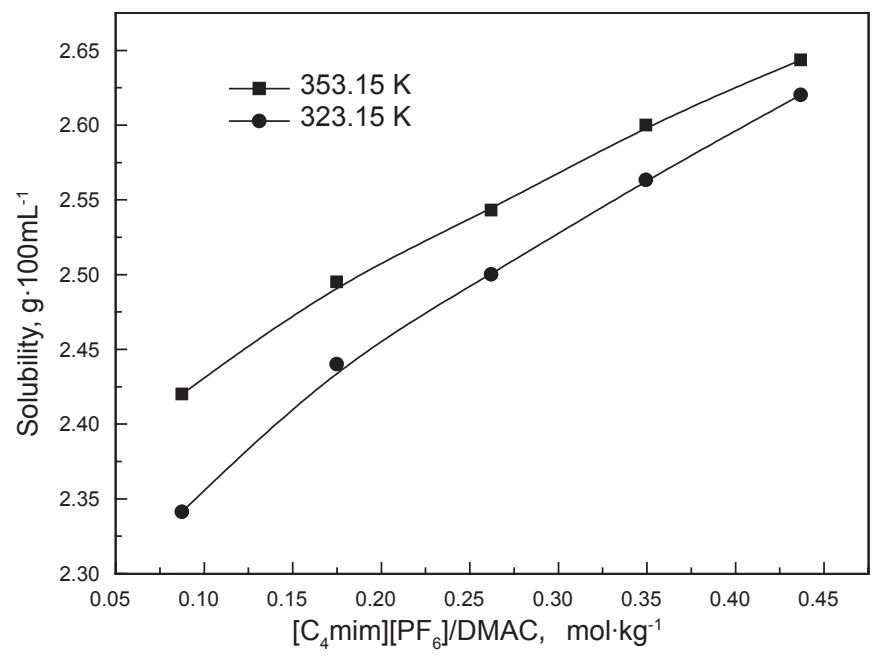

Fig. 8 Effect of temperature and concentration on solubility of $\beta$-CD in $\left[\mathrm{C}_{4} \mathrm{mim}\right]\left[\mathrm{PF}_{6}\right] / \mathrm{DMAC}$ mixture

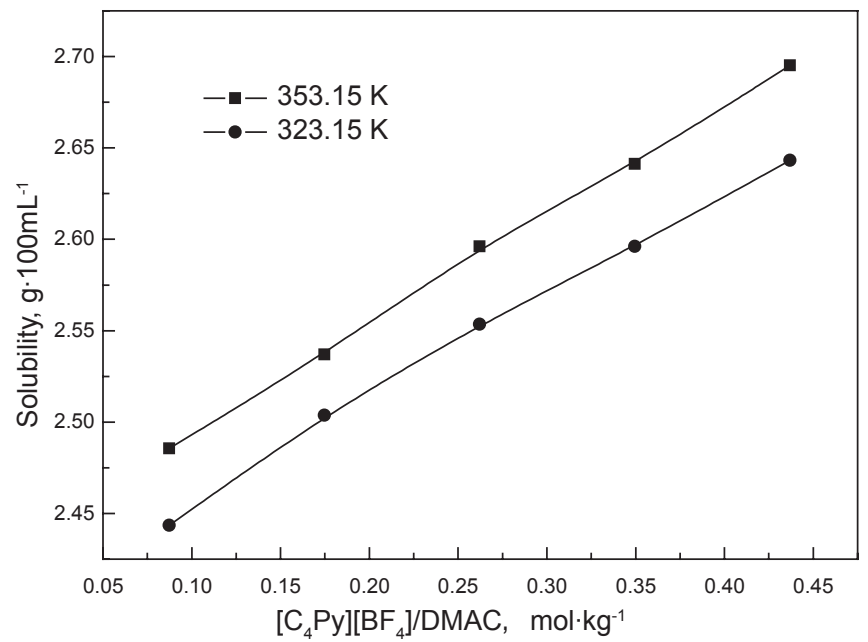

Fig. 9 Effect of temperature and concentration on solubility of $\quad \beta-C D$ in $\left[\mathrm{C}_{4} \mathrm{Py}\right]\left[\mathrm{BF}_{4}\right] /$ DMAC mixture

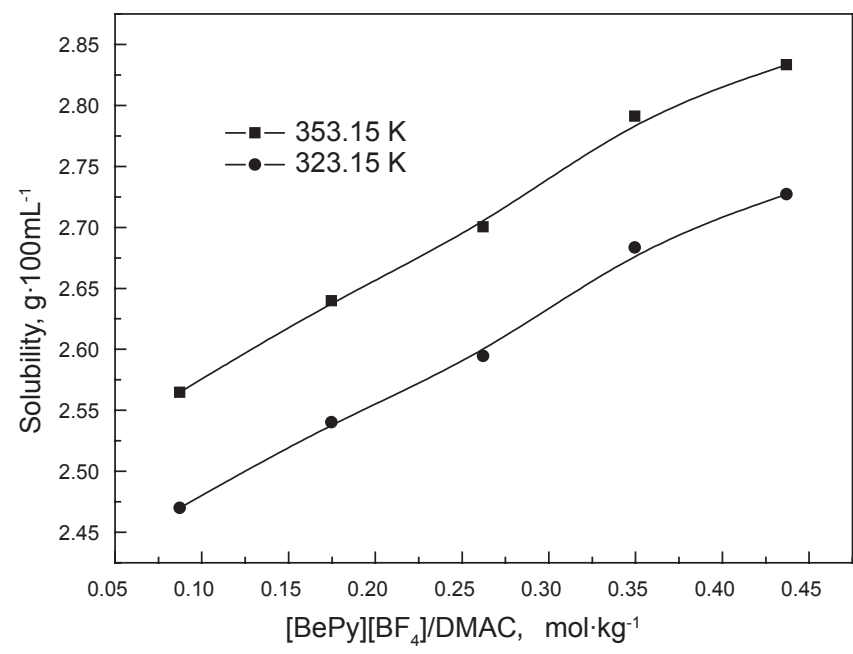

Fig. 10 Effect of temperature and concentration on solubility of $\beta$-CD in $[\mathrm{BePy}]\left[\mathrm{BF}_{4}\right] / \mathrm{DMAC}$ mixture

imidazolium ILs and $\beta$-CD, because isoquinolinium ILs has a larger size of cation, resulting in larger space blockage. Strong $\pi-\pi$ interactions could be formed between conjugated aromatic ring of isoquinolinium ILs and $\beta-\mathrm{CD}$, but the $\pi-\pi$ interactions are weaker than H-bonds, so the solubility of $\beta-\mathrm{CD}$ in isoquinolinium ILs is lower than that in imidazolium ILs.

For pyridinium ILs and isoquinolinium ILs, Figs. 11 and 12 show that the charge density difference between cations and anions has a great effect on the dissolution of $\beta$-CD. The higher the charge density difference, the greater the solubility of $\beta$-CD (the positive charge of isoquinolinium cation could move in the whole aromatic-ring system, so the charge density of cation of isoquinolinium is lower than that of pyridinium). Moreover, the conjugated aromatic rings of isoquinolinium ILs could form strong $\pi-\pi$ interactions with $\beta-\mathrm{CD}$, also promoting the dissolution of $\beta-\mathrm{CD}$. The experiment results (Figs. 11-13) showed that the solubility 
of $\beta$-CD in imidazolium ILs which is greater than that in pyridinium ILs could be explained as follows: The methyl group on the $\mathrm{C}(1)$ position of the imidazolium ring has a special function, because both as electron-providing group and interaction with head-group of imidazolium ring by alkyl$\pi$ bonding it could lower the density of positive charge and increase the difference of charge density between cation and anion for imidazolium ILs. Thereby the ability of forming hydrogen bond with anions in imidazolium ILs is improved and the solubility of $\beta$-CD in imidazolium ILs is higher than in pyridinium ILs.

Theoretically, the hydrogen atoms between two nitrogen atoms on imidazolium rings have larger charge density, which could easily form $\mathrm{H}$-bonds with hydroxyl of $\beta$-CD and accelerate the dissolution of $\beta$-CD. But the experiment results (Fig. 14) show that the acidic hydrogen on the imidazolium rings has little effect on the dissolution of $\beta-\mathrm{CD}$, and the reason might be that the large size of $\beta-\mathrm{CD}$ generates large space blockage, resulting in weak hydrogen bonding. On the other hand, for ILs with the same cation tail group and

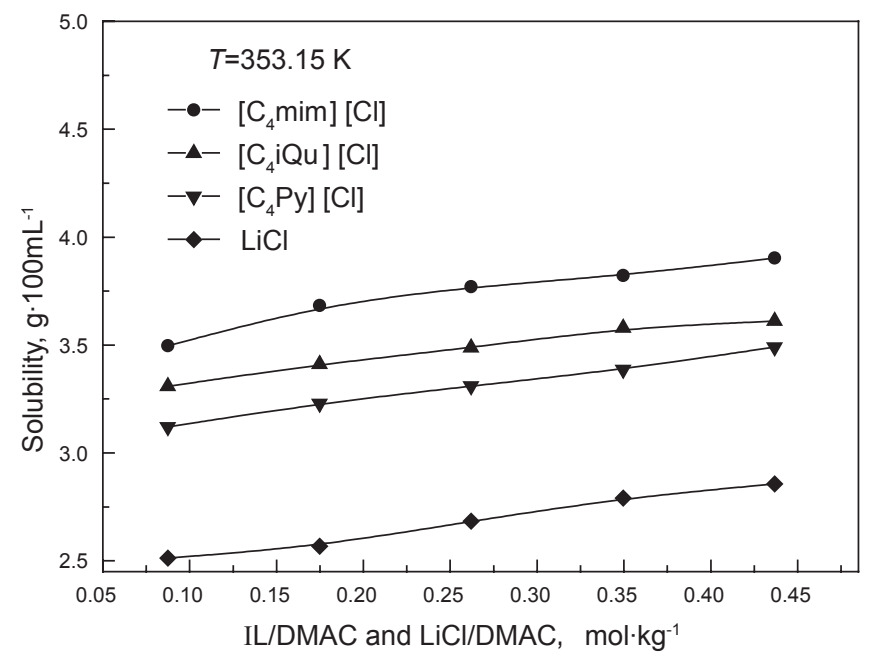

Fig. 11 Solubility of $\beta-C D$ in different IL/DMAC and $\mathrm{LiCl} / \mathrm{DMAC}$ mixtures

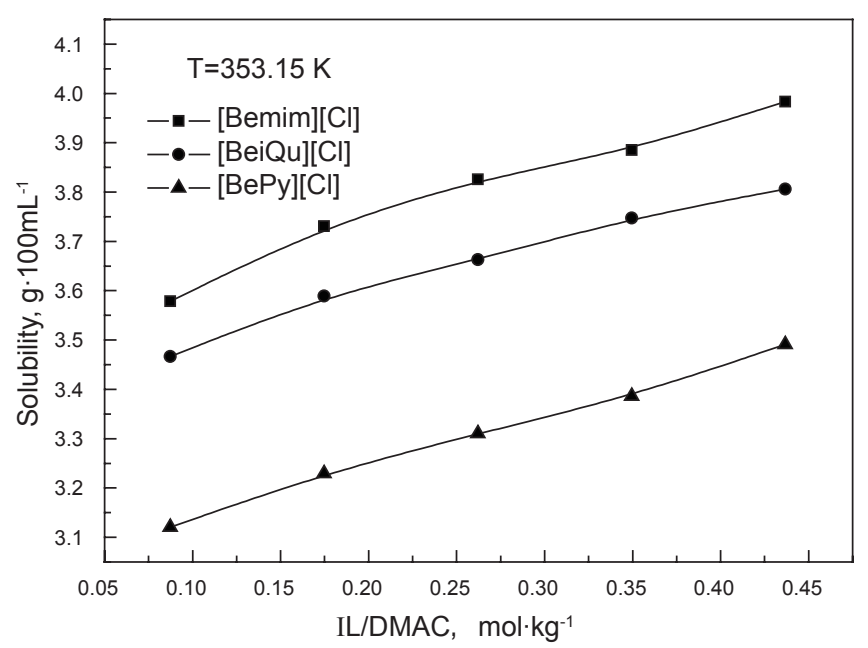

Fig. 12 Solubility of $\beta$-CD in different IL/DMAC mixtures

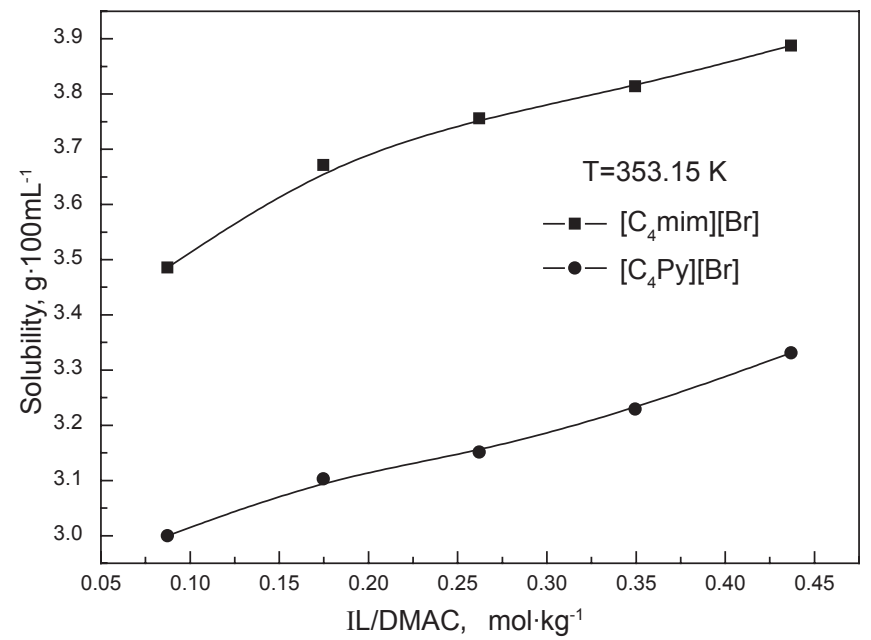

Fig. 13 Solubility of $\beta$-CD in different IL/DMAC mixtures

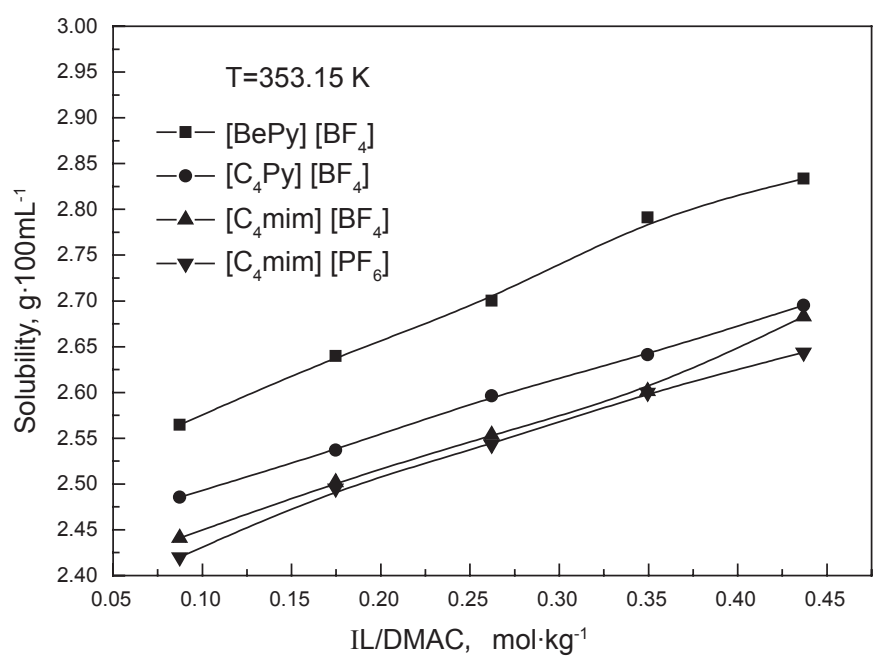

Fig. 14 Solubility of $\beta$-CD in different IL/DMAC mixtures

weakly-coordinated anion $\left(\left[\mathrm{BF}_{4}\right]^{-}\right.$or $\left.\left[\mathrm{PF}_{6}\right]^{-}\right)$, a cation head group of pyridinium is a 6-ring structure and has the same ring number as the cell structure of $\beta-C D$, hence $\beta-C D$ has greater solubility in pyridinium ILs than in imidazolium ILs.

\subsection{Effect of cation tail groups on the solubility of $\beta-\mathrm{CD}$}

Cation tail groups have great impact on the property of ionic liquids. For pyridinium ILs (Figs. 14 and 17), the solubility of $\beta-\mathrm{CD}$ decreases in the order of $[\mathrm{BePy}][\mathrm{Cl}]>$ $\left[\mathrm{C}_{4} \mathrm{Py}\right][\mathrm{Cl}] ;[\mathrm{BePy}]\left[\mathrm{BF}_{4}\right]>\left[\mathrm{C}_{4} \mathrm{Py}\right]\left[\mathrm{BF}_{4}\right]$. For isoquinolinium ILs (Fig. 15), the solubility of $\beta$-CD decreases in the order of $[\mathrm{BeiQu}][\mathrm{Cl}]>\left[\mathrm{C}_{4} \mathrm{iQu}\right][\mathrm{Cl}]$; For imidazolium ILs (Fig. 16), the solubility of $\beta-\mathrm{CD}$ decreases in the order of [Bemim] $[\mathrm{Cl}]$ $>\left[\mathrm{C}_{4} \mathrm{mim}\right][\mathrm{Cl}]$. Therefore, for ILs with the same anion tail groups and at the same temperature, the solubility of $\beta-C D$ in ILs decreases in the order of benzyl $>$ butyl. The reason might 
be that there are strong $\pi-\pi$ interactions formed between $\pi$ bond of benzyl and $\beta$-CD, promoting the dissolution of $\beta$-CD.

\subsection{Effect of anion structures on the solubility of $\beta-\mathbf{C D}$}

It can be seen from Figs. 14, 16 and 17 that the solubility of $\beta$-CD in IL/DMAC is also related to the anion species of ILs. For ILs with the same cation, at the same temperature, the solubility of $\beta$-CD decreases in the order of $\left[\mathrm{C}_{4} \mathrm{Py}\right][\mathrm{Cl}]$ $\left.\left.>\left[\mathrm{C}_{4} \mathrm{Py}\right]\right] \mathrm{Br}\right]>\left[\mathrm{C}_{4} \mathrm{Py}\right]\left[\mathrm{BF}_{4}\right],\left[\mathrm{C}_{4} \mathrm{iQu}\right][\mathrm{Cl}]>\left[\mathrm{C}_{4} \mathrm{iQu}\right][\mathrm{Br}]$, $\left.\left.\left[\mathrm{C}_{4} \mathrm{mim}\right]\right] \mathrm{Cl}\right]>\left[\mathrm{C}_{4} \mathrm{mim}\right][\mathrm{Br}]>\left[\mathrm{C}_{4} \mathrm{mim}\right]\left[\mathrm{BF}_{4}\right]>\left[\mathrm{C}_{4} \mathrm{mim}\right]\left[\mathrm{PF}_{6}\right]$. Namely, the solubility of $\beta-C D$ decreases in the order: ionic liquids with halogen anion $\left([\mathrm{Cl}]^{-},[\mathrm{Br}]^{-}\right)>$weaklycoordinated anion $\left(\left[\mathrm{BF}_{4}\right]^{-},\left[\mathrm{PF}_{6}\right]^{-}\right)$.

It was considered that that $\mathrm{H}$-bond was formed between the anion of ILs and the hydroxyl of $\beta$-CD, which weakened the $\mathrm{H}$-bond between $\beta$-CD molecules and within the interior of $\beta$-CD molecule, resulting in increasing solubility of $\beta$-CD. From the viewpoint of electron effect, compared with weakly-coordinated anions $\left(\left[\mathrm{BF}_{4}\right]^{-},\left[\mathrm{PF}_{6}\right]^{-}\right)$, anions $[\mathrm{Cl}]^{-}$or $[\mathrm{Br}]^{-}$are the stronger $\mathrm{H}$-bond contributor and more likely to form $\mathrm{H}$-bond with the hydroxyl of $\beta$-CD. From the viewpoint of spatial effect, the volume of halogen anions $\left([\mathrm{Cl}]^{-},[\mathrm{Br}]^{-}\right)$ is smaller than that of $\left[\mathrm{BF}_{4}\right]^{-}$and $\left[\mathrm{PF}_{6}\right]^{-}$, so the ionic liquid with halogen anions has higher electron cloud density and electronegativity intensity, and is more likely to form H-bond with the hydroxyl of $\beta$-CD. Because the central atom of $\left[\mathrm{BF}_{4}\right]^{-}$ is smaller than that of $\left[\mathrm{PF}_{6}\right]^{-},\left[\mathrm{BF}_{4}\right]^{-}$has higher negative charge density. So the solubility of $\beta-\mathrm{CD}$ in ionic liquid with $\left[\mathrm{BF}_{4}\right]^{-}$anions is greater than that with $\left[\mathrm{PF}_{6}\right]^{-}$anions. The electron density of cations in ionic liquids with $[\mathrm{Cl}]^{-}$or $[\mathrm{Br}]^{-}$ anion is smaller than that of $\mathrm{Li}^{+}$, so the charge difference between positive charge and negative charge in IL/DMAC is bigger than that in $\mathrm{LiCl} / \mathrm{DMAC}$ mixture. To maintain electric neutrality, the anion in ILs with $[\mathrm{Cl}]^{-}$or $[\mathrm{Br}]^{-}$is more likely to form $\mathrm{H}$-bond with $\beta$-cyclodextrin to lower the negative charge density, so $\beta$-CD has greater solubility in IL/DMAC with $[\mathrm{Cl}]^{-}$or $[\mathrm{Br}]^{-}$anion than in $\mathrm{LiCl} / \mathrm{DMAC}$.

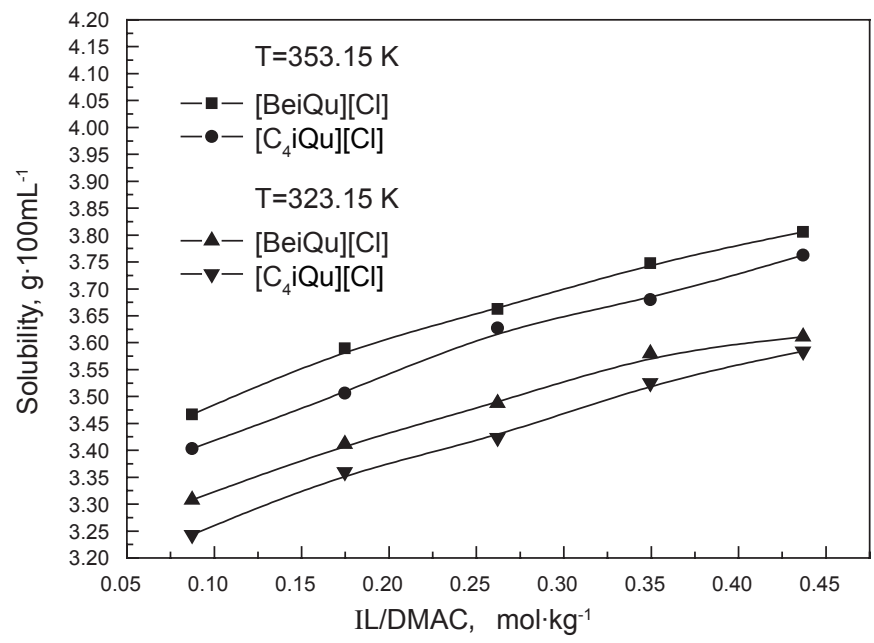

Fig. 15 Effect of different cation substituents on the solubility of $\beta$-CD in isoquinolinium ILs

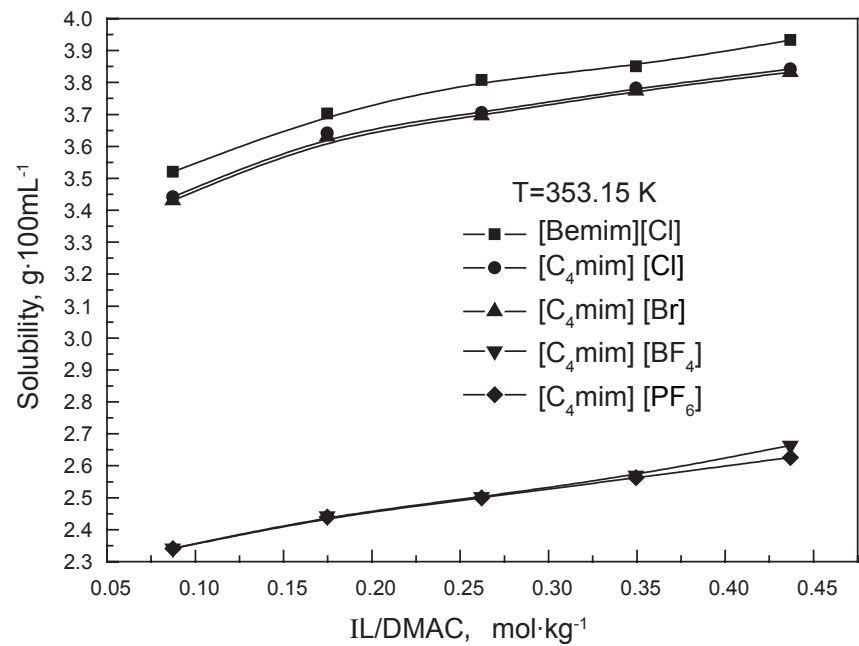

Fig. 16 Effect of different cation substituents and anion on the solubility of $\beta$-CD in imidazolium Ils

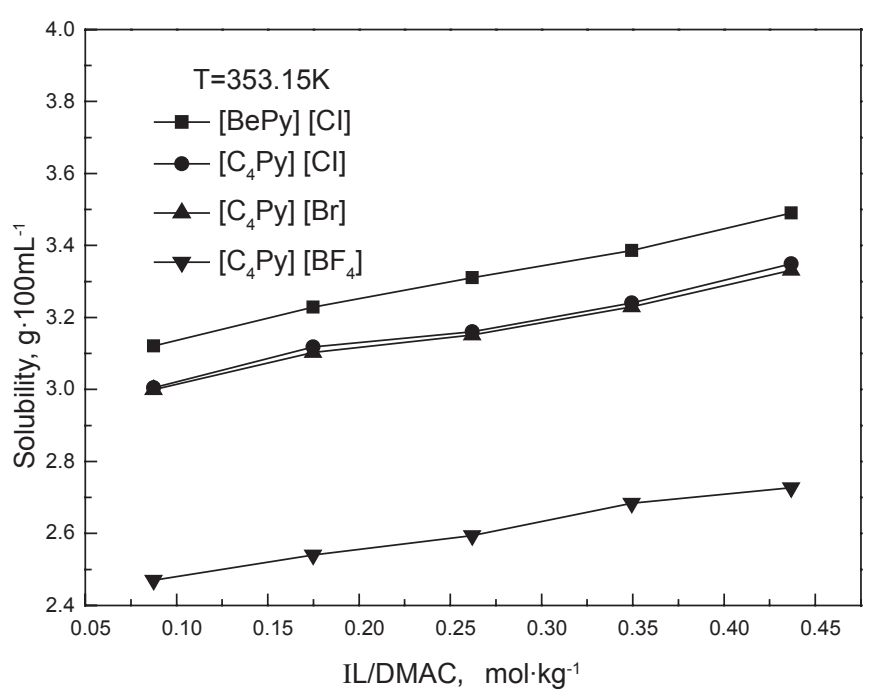

Fig. 17 Effect of different cation substituents and anion on the solubility of $\beta$-CD in pyridinium Ils

\section{Conclusions}

From this study on the solubility of $\beta-\mathrm{CD}$ in $\mathrm{LiCl} / \mathrm{DMAC}$ and IL/DMAC, the following conclusions are drawn: 1) The solubility of $\beta$-CD increases in IL/DMAC system with increasing temperature, whereas it decreases in $\mathrm{LiCl} / \mathrm{DMAC}$ system. At the same temperature, the solubility of $\beta-\mathrm{CD}$ increases with increasing concentration of IL and $\mathrm{LiCl}$ in mixed solvents. 2) Under the same conditions (temperature and concentration), for the ILs with $[\mathrm{Cl}]^{-}$or $[\mathrm{Br}]^{-}$anion and the same alkyl tail group of cations, the solubility of $\beta$-CD decreases in the order of imidazolium $>$ isoquinolinium $>$ pyridinium. For ILs with weakly-paired anions $\left(\left[\mathrm{BF}_{4}\right]^{-}\right.$ and $\left.\left[\mathrm{PF}_{6}\right]^{-}\right)$and the same cations, the solubility of $\beta-\mathrm{CD}$ decreases in the order of pyridinium > imidazolium. 3) Under the same conditions, for the ILs with different cation tail groups, the solubility of $\beta-\mathrm{CD}$ decreases in the order 
of $[\mathrm{Bemim}][\mathrm{Cl}]>\left[\mathrm{C}_{4} \mathrm{mim}\right][\mathrm{Cl}] ;[\mathrm{BePy}][\mathrm{Cl}]>\left[\mathrm{C}_{4} \mathrm{Py}\right][\mathrm{Cl}]$; $\left.[\mathrm{BeiQu}][\mathrm{Cl}]>\left[\mathrm{C}_{4} \mathrm{iQu}\right][\mathrm{Cl}] ;[\mathrm{BePy}]\left[\mathrm{BF}_{4}\right]>\left[\mathrm{C}_{4} \mathrm{Py}\right]\left[\mathrm{BF}_{4}\right] .4\right)$ For the ILs with common cation, under the same conditions, the solubility of $\beta-\mathrm{CD}$ decreases in the order of $\left[\mathrm{C}_{4} \mathrm{Py}\right][\mathrm{Cl}]$ $\left.\left.>\left[\mathrm{C}_{4} \mathrm{Py}\right]\right] \mathrm{Br}\right]>\left[\mathrm{C}_{4} \mathrm{Py}\right]\left[\mathrm{BF}_{4}\right],\left[\mathrm{C}_{4} \mathrm{iQu}\right][\mathrm{Cl}]>\left[\mathrm{C}_{4} \mathrm{iQu}\right][\mathrm{Br}]$, $\left.\left.\left[\mathrm{C}_{4} \mathrm{mim}\right]\right] \mathrm{Cl}\right]>\left[\mathrm{C}_{4} \mathrm{mim}\right][\mathrm{Br}]>[\mathrm{C} 4 \mathrm{mim}]\left[\mathrm{BF}_{4}\right]>\left[\mathrm{C}_{4} \mathrm{mim}\right]\left[\mathrm{PF}_{6}\right]$.

\section{Acknowledgments}

The authors are grateful to the Foundation of Innovation for Middle-aged and Youth, CNPC (04E7031), Program for New Century Talents in Universities, Ministry of Education, China (NCET-06-0088), and the National Natural Science Foundation of China (40673043 and 20576073) for the financial support.

\section{References}

Chatjigakis A K, Donze C and Coleman A W. Solubility behavior of $\beta$-cyclodextrin in water/cosolvent mixtures. Analytical Chemistry. 1992. 64(14): 1632-1634

Denadai Â M L, Sinisterra R D, et al. Novel pharmaceutical composition of bradykinin potentiating penta peptide with $\beta$-cyclodextrin: Physical-chemical characterization and anti-hypertensive evaluation. International Journal of Pharmaceutics. 2007. 336(1): 90-98

Earle M J, Seddon K R and McCormac P B. The first high yield green route to a pharmaceutical in a room temperature ionic liquid. Green Chemistry. 2000. 2(6): 257-304

Engeldinger E, Armspach D and Matt D. Capped cyclodextrins.
Chemical Reviews. 2003. 103(11): 4147-4174

Huddleston J G, Willauer H D, Swatloski P, et al. Room temperature ionic liquids as novel media for clean liquid-liquid extraction. Chemical Communications. 1998. 16: 1765-1766

Hu Y F and Guo T M. Effect of the Structures of Ionic Liquids and Alkylbenzene-Derived Amphiphiles on the Inhibition of Asphaltene Precipitation from CO2-Injected Reservoir Oils. Langmuir. 2005. 21(18): 8168-8174

Kawaguchi Y, Nishiyama T, Okada M, et al. Complex formation of poly ( $\varepsilon$-caprolactone) with cyclodextrins. Macromolecules. 2000. 33(12): $4472-4477$

Liu Y S, Zhang Z X, Zhang G F, et al. Effect of the Structure of Cations and Anions of Ionic Liquids on Separation of Aromatics from Hydrocarbon Mixtures. Petroleum science. 2006. 3(3): 73-78

Mohammad A E and Razieh Y. Molecularly imprinted poly $\beta$-cyclodextrin polymer: Application in protein refolding. Biochimica et Biophysica Acta. 2007. 1770(6): 943-950

Naidoo K J, Chen J Y-J, Jansson J L M, et al. Molecular Properties Related to the Anomalous Solubility of $\beta$-Cyclodextrin. J. Phys. Chem. B. 2004. 108(14): 4236-4238

Tang B, Zhang G Y, Liu Y, Han F. Studies on catalytic spectrophotometry using $\quad \beta$-cyclodextrin polymer-Schiff base metal complex as mimetic enzyme. Analytica Chimica Acta. 2002. 459(1): 83-91

Wasserscheid P and Keim W. Ionic liquids-new "solutions" for transition metal catalysis. Angew. Chem. Int. Ed. 2000. 39: 3772-3789

Welton T. Room-temperature ionic liquids: Solvents for synthesis and catalysis. Chemical Reviews. 1999. 99(8): 2071-2083

Wilkes J S, Zaworotko M J. Air and water stable 1-ethyl-3methylimidazolium based ionic liquids. Chemical Communications. 1992. 13: $965-966$

(Edited by Zhu Xiuqin) 